\title{
HUBUNGAN PERSEPSI IBU TENTANG HYPNOBIRTHING DENGAN PENGURANGAN RASA NYERI PADA IBU BERSALIN NORMAL DI KLINIK DIANA MEDAN TAHUN 2018
}

\author{
Relationship With Kilroy Reduction Method Pain In The Mother Birthing Clinic \\ In Normal Diana field year 2018
}

\author{
Yulida Effendi Nasution ${ }^{1 *}$, Asrul ${ }^{2}$ \\ ${ }^{1}$ Dosen D4 Kebidanan, Institut Kesehatan Helvetia Medan \\ ${ }^{2}$ Dosen D4 Kebidanan, Institut Kesehatan Helvetia Medan \\ *yulidaeffendi@helvetia.ac.id
}

\begin{abstract}
ABSTRAK
Hypnobirthing merupakan kombinasi antara proses kelahiran alami dengan hypnosis untuk membangun persepsi positif dan rasa percaya diri serta menurunkan ketakutan, kecemasan, tenang dan panik sebelum dan setelah persalinan. Hypnobirthingbertujuanagar ibu dapat melahirkan dengan nyaman, cepat dan lancar dan menghilangkan rasa sakit melahirkan tanpa bantuan obat bius apapun. Tujuan penelitian ini untuk mengetahui hubungan persepsi ibu tentang hypnobirthing dengan pengurangan rasa nyeri pada ibu bersalin. Penelitian ini menggunakan survey analitik dengan pendekatan cross sectional. Populasi pada penelitian ini adalah ibu bersalin di Klinik Diana Tahun 2018, jumlah sampel sebanyak 30 responden diambil dengan persepsi ibu tentang total sampling. Hasil penelitian yang di dapatkan dari ibu yang melakukan persepsi ibu tentang Hypnobirthing dari 30 responden dapat di ketahui bahwa ada17 responden $(56,7 \%)$ dengan pelaksanaan metode hypnobirthing dan mengalami nyeri sedang dan 18 responden $(60,0 \%)$ dan minoritas ibu mengalami persepsi ibu tentang hypnobirthing sebanyak 13 responden $(43,3 \%)$ dan yang mengalami nyeri hebat sebanyak 12 responden $(40,0 \%)$. Setelah dilakukan uji Chi-Square terdapat hubungan persepsi ibu tentang Hypnobeirthing dengan pengurangan rasa nyeri pada ibu bersalin $p$ value e 0,013 sig $\alpha<0,005$. Dari hasil penelitian, ada hubungan metode hypnobirthing dengan pengurangan rasa nyeri pada ibu bersalin di Klinik Diana Tahun 2018. Maka disarankan kepada tenaga kesehatan agar kiranya dapat mempromosikan persalinan dengan persepsi ibu tentang Hypnoberthing dan senantiasa turut serta dalam memberikan informasi kepada ibu-ibu tentang persiapan selama kehamilan dan persalinan dengan menggunakan persepsi ibu tentang hypnoberthing.
\end{abstract}

Kata Kunci : : Persepsi Ibu Tentang Hypnobirthing, dan Pengurangan Rasa Nyeri

\section{ABSTRACT}

Hypnobirthing is a combination of natural birth process and hypnosis to build positive perception and self-confidence and reduce fear, anxiety, calm and panic before and after childbirth. Hypnobirthing aims for mothers to give birth comfortably, quickly and smoothly and relieve childbirth without the help of any anesthetic. The purpose of this study was to determine the relationship between hypnobirthing methods and the reduction of pain in maternity mothers.

This study uses an analytical survey with a cross sectional approach. The population in this study were mothers giving birth at Diana Clinic in 2018, the number of samples of 30 respondents was taken by the total sampling method.

The research results obtained from mothers who did the Hypnobirthing method from 30 respondents can be seen that there were 17 respondents $(56.7 \%)$ with the implementation of the hypnobirthing method and experienced moderate pain and 18 respondents $(60.0 \%)$ and minorities of mothers experienced hypnobirthing method as many as 13 respondents (43.3\%) and experienced severe pain as many as 12 respondents (40.0\%). After the Chi-Square test, there was a relationship between the method of Hypnobeirthing and the reduction of pain in the maternity mother $p$ value e 0,013 sig $\alpha$ $<0,005$. From the results of the study, there is a relationship between the hypnobirthing method and the reduction of pain in maternity at Diana Clinic in 2018

So it is advisable for health workers to promote childbirth with the Hypnoberthing method and always participate in providing information to mothers about preparation during pregnancy and childbirth using the hypnoberthing method.

Keywords $\quad$ : Kilroy, Method and reduction of pain 


\section{PENDAHULUAN}

Persalinan adalah hal yang dinantikan seorang ibu. Berbulan-bulan lamanya ibu menantikan kelahiran sibuah hati, Ibu dan keluarga akan melakukan berbagai cara untuk keselamatan bayinya dan ibu juga rela mempertaruhkan nyawa sewaktu bersalin. Persalinan juga di sertai rasa nyeri yang membuat kebahagian yang di dambakan diliputi oleh rasa takut dan cemas.Partus macet atau lama yang dialami selama persalinan salah satunya disebabkan oleh lamanya kopingibu terhadap rasa nyeri yang dialami selama persalinan.Nyeri persalinan dialami hampir sekitar $90 \%$ ibu bersalin.

Nyeri tersebut dialami oleh primipara dan multipara.Intensitas nyeri persalinan pada primipara lebih berat dikarenakan intensitas kontraksi lebih sakit adalah hal yang wajar dan dibutuhkan saat melahirkan normal. Saat wanita yang melahir

relaksasi yang membuat proses kelahiran jadi lebih mudah dan bebas stres. Hypnobirthing bertujuan agar ibu dapat melahirkan dengan nyaman, cepat dan lancar dan menghilangkan rasa sakit melahirkan tanpa bantuan obat bius apapun.(1)

Menurut Worltd Health Organization (WHO).Hypnobirthing adalah suatu bantuk terapi alternatif yang secara menyeluruh membantu ibu untuk rileks, tenang, dan tetap dalam keadaan sadar sepenuhnya. Hybnobirthing adalah salah satu cabang dari hypnosis.(2)

Menurut data survei Demografi kesehatan Indonesia (SDKI) pada tahun 2011, angka kematian ibu 228/100.000 kelahiran hidup dan terakhir pada tahun 2012 angka itu naik menjadi tersebut merupakan angka tertinggi dengan 450 kematian ibu per Indonesia saat ini tergolong masih cukup tinggi yaitu mencapai 228/100.000 kelahiran. Berdasarkan berat terutama pada kala I. Hal tersebut disebabkan oleh penipisan serviks primipara terjadi lebih dahulu dari pada dilatasi serviks.Selain itu, primipara belum memiliki pengalaman terhadap nyeri persalinan sebelumnya yang menimbulkan ketegangan emosi dan cemas sehingga memperberat persepsi nyeri.Maka untuk meringankan rasa nyeri banyak ibu yang menggunakan metode Hypnobirthing.

Hypnobirthing merupakan kombinasi antara proses kelahiran alami dengan hypnosis untuk membangun persepsi positif dan rasa percaya diri serta menurunkan ketakutan, kecemasan, tenang dan panik sebelum, selama dan setelah persalinan.Hypnobirthing

mengeksplorasikan mitos bahwa rasa

kan terbebas dari rasa takut, otot tubuhnya, termasuk otot rahim, akan mengalami

359/100.000 kelahiran hidup. Angka kematian ibu mulai menjadi sorotan terkait sulitnya mencapai target MGDs (millennium Development Goals) yang tinggal dua tahun lagi menurunkan angka kematian menjadi 102/100.000 kelahiran hidup pada tahun 2015, untuk menurunkan angka kematian ibu diperlukan upaya-upaya yang terkait dengan kehamilan, kelahiran dan nifas (WHO, 2011). Menurut dinas kesehatan provinsi jawa tengah pada tahun 2012 AKI di jawa tengah meningkat menjadi $116,34 / 100.00$ KH.(3)

Menurut data WHO, sebanyak 99\% kematian ibu akibat masalah persalinan terjadi di negara berkembang. Rasio kematian ibu

100.00kelahiran bayi hidup. Angka kematian ibu melahirkan di sasaran pembangunan MDGs, kematian ibu melahirkan ditetapkan pada angka 110/100.000 kelahiran. Sementara 
Indonesia menetapkan target AKI 125/100.000 pada 2015.(4)

Penelitian Marpaung (2011) dengan judul Gambaran Kecemasan dan Nyeri Persalinan pada Ibu Primigravida di Klinik Bersalin Sally Medan Tahun 2011 menunjukan sebagian besar ibu primigravida mengalami nyeri berat, sebanyak 54\% mengalami nyeri sedang, dan sebanyak $46 \%$ mengalami nyeri ringan.(5)

Penelitian Munawaroh (2009) dengan judul Gambaran Nyeri Persalinan Multigravida di BPS Salamah Pekalongan menunjukan ibu multigravida sebagian besar mengalami nyeri ringan sebanyak $63 \%$ sedangkan nyeri berat sebanyak 37\%.(6)

Hasil penelitian marfuah tahun 2010 tentang perbedaan intensitas nyern di BPM pada 30 ibu primipara menunjukkan ibu yang dilakukan hypnoteraphy dalam persalinan normal mengalami nyeri berat $40 \%$, nyeri sedang $53,3 \%$, nyeri ringan $6,7 \%$,

\section{METODE}

Desain penelitian digunakan dalam penelitian ini adalah survei analitik dimana peneliti ingin mmengetahui apakah ada hubungan

\section{HASIL DAN PEMBAHASAN}

Analisis Univariat

Dari hasil penelitian data yang di peroleh berdasarkan pengisian kuesioner terhadap 30 responden mengenai Hubungan persepsi ibu tentang sedangkan yang tidak diberikan hypnoteraphy mengalami nyeri berat $66,7 \%$, nyeri sedang $30 \%$, nyeri ringan $3,3 \%$.

Berdasarkan survey awal yang telah dilakukan peneliti diKlinik Diana Medan Tahun 2018 pada bulan Januari 2018 terdapat 10 orang ibu bersalin yang melakukan persrpsi ibu tentng Hypnobirthing Dalam hal ini ibu bersalin yang menggunakan metode Hypnobirthing mengatakan bahwa,persepsi ibu tentang hybnobirthing tersebut dapat mengurangi rasa sakit saat bersalin dan ibu merasa nyaman bersalin di klinik Diana Medan.

Berdasarkan uraian permasalahan diatas, maka penulis tertarik melakukan penelitian tentang “ Hubungan persepsi ibu tenang hypnobrthing dengan pengurangan rasa nyeri pada ibu bersalin normal di Klinik Diana Medan Tahun 2018 “

pendekatan persepsi ibu tentang Hypnobirthing dengan pengurangan rasa nyeri pada ibu bersalin normal di Klinik Diana medan tahun 2018.

Hypnoberthing Dengan Pengurangan rasa nyeri pada Ibu Bersalin Normal Di klinik Diana Medan Tahun 2018 maka diperoleh hasil sebagai berikut:

Tabel 1. Distribusi frekuensi jawaban responden tentang hubungan persepsi ibu tentag hybnoberthing dengan pengurangan rasa nyeri pada ibu bersalin normal di Klinik Diana Medan Tahun 2018.

\begin{tabular}{|c|c|c|c|c|c|c|c|}
\hline \multirow{3}{*}{ No } & \multirow{3}{*}{ Pertanyaan } & \multicolumn{6}{|c|}{ Jawaban } \\
\hline & & \multicolumn{2}{|c|}{ Baik } & \multicolumn{2}{|c|}{ Kurang } & \multicolumn{2}{|c|}{ Total } \\
\hline & & $\mathbf{f}$ & $\%$ & f & $\%$ & $\mathbf{f}$ & $\%$ \\
\hline 1 & $\begin{array}{l}\text { Apakah dengan relaksasi mampu } \\
\text { membuat kondisi ibu nyaman? }\end{array}$ & 16 & 53,3 & 14 & 46,7 & 30 & 100 \\
\hline 2 & $\begin{array}{l}\text { Apakah saat bersalin Ibu dipimpin } \\
\text { untuk melatih pernapasan oleh } \\
\text { Bidan }\end{array}$ & 19 & 63,3 , & 11 & 36,3 & 30 & 100 \\
\hline
\end{tabular}




\begin{tabular}{|c|c|c|c|c|c|c|c|}
\hline \multirow{3}{*}{ No } & \multirow{3}{*}{ Pertanyaan } & \multicolumn{6}{|c|}{ Jawaban } \\
\hline & & \multicolumn{2}{|c|}{ Baik } & \multicolumn{2}{|c|}{ Kurang } & \multicolumn{2}{|c|}{ Total } \\
\hline & & f & $\%$ & f & $\%$ & f & $\%$ \\
\hline 3 & $\begin{array}{ll}\text { Apakah ada kesulitan } & \text { saat } \\
\text { melakukan relaksasi tubuh? } & \end{array}$ & 18 & 60,0 & 12 & 40,0 & 30 & 100 \\
\hline 4 & $\begin{array}{l}\text { Apakah bersalin dengan persepsi } \\
\text { ibu tentang Hypnobirthing Ibu } \\
\text { dibuat tertidur selama menjalanin } \\
\text { proses persalinan? }\end{array}$ & 12 & 40,0 & 18 & 60,0 & 30 & 100 \\
\hline 5 & $\begin{array}{lcr}\text { Apakah bidan menggunakan } \\
\text { persepsi ibu } & \text { tentang } \\
\text { Hipnobirthing (Hinotis)? } & \end{array}$ & 13 & 43,3 & 17 & 56,7 & 30 & 100 \\
\hline 6 & $\begin{array}{l}\text { Apakah dengan relaksasi ini, Ibu } \\
\text { merasa lancar dengan proses } \\
\text { persalinan? }\end{array}$ & 16 & 53,3 & 14 & 46,7 & 30 & 100 \\
\hline 7 & $\begin{array}{l}\text { Apakah ibu merasa senang dan } \\
\text { nyaman dengan menggunakan } \\
\text { persepsi ibu } \\
\text { Hypnobirthing? }\end{array}$ & 15 & 50,0 & 15 & 50,0 & 30 & 100 \\
\hline 8 & $\begin{array}{l}\text { Apakah Ibu merasa senang dengan } \\
\text { Hipnotis yang di lakukan bidan } \\
\text { pada proses persalinan? }\end{array}$ & 17 & 56,7 & 13 & 43,3 & 30 & 100 \\
\hline 9 & $\begin{array}{l}\text { Apakah Ibu susah melakukan } \\
\text { langkah-langkah Hipnotis yang di } \\
\text { lakukan Bidan selama persalinan } \\
\text { Ibu? }\end{array}$ & 19 & 63,3 & 11 & 36,7 & 30 & 100 \\
\hline 10 & $\begin{array}{l}\text { Apakah dengan Hipnotis yang di } \\
\text { lakukan Bidan pada persalinan, } \\
\text { Ibu merasa senang? }\end{array}$ & 20 & 66,7 & 10 & 33,3 & 30 & 100 \\
\hline
\end{tabular}

Tabel 2. Distibusi frekuensi jawaban responden dengan pengurangan rasa nyeri pada ibu bersalin di Klinik Diana Medan Tahun 2018.

\begin{tabular}{|c|c|c|c|c|c|c|c|}
\hline \multirow{3}{*}{ No } & \multirow{3}{*}{ Pertanyaan } & \multicolumn{6}{|c|}{ Jawaban } \\
\hline & & \multicolumn{2}{|c|}{ Nyeri hebat } & \multicolumn{2}{|c|}{$\begin{array}{l}\text { Nyeri } \\
\text { sedang }\end{array}$} & \multicolumn{2}{|c|}{ Jumlah } \\
\hline & & $\mathbf{f}$ & $\%$ & $\mathbf{f}$ & $\%$ & $\mathbf{f}$ & $\%$ \\
\hline 1 & $\begin{array}{l}\text { Apakah nyeri pada Ibu sangat } \\
\text { hebat pada saat Ibu bersalin? }\end{array}$ & 21 & 70,0 & 9 & 30,0 & 30 & 100 \\
\hline 2 & $\begin{array}{l}\text { Apakah nyeri pada persalinan Ibu } \\
\text { tetap bisa tahan? }\end{array}$ & 13 & 43,3 & 17 & 56,7 & 30 & 100 \\
\hline 3 & $\begin{array}{l}\text { Apakah nyeri hebat selama } \\
\text { persalinan Ibu, Ibu ada keraguan } \\
\text { seperti terjadi yang tidak di } \\
\text { inginkan? }\end{array}$ & 18 & 60,0 & 12 & 40,0 & 30 & 100 \\
\hline 4 & $\begin{array}{l}\text { Apakah nyeri yang Ibu rasakan } \\
\text { terganggu kelancaran proses } \\
\text { persalinan? }\end{array}$ & 18 & 60,0 & 12 & 40,0 & 30 & 100 \\
\hline 5 & $\begin{array}{l}\text { Apakah nyeri dari awal sampai } \\
\text { akhir pada persalinan Ibu tetap } \\
\text { tahan dan kuat? }\end{array}$ & 16 & 53,3 & 14 & 46,7 & 30 & 100 \\
\hline
\end{tabular}


Tabel3 Distribusi frekuensi persepsi ibu tentang Hypnobirthing Diklinik Diana medan Tahun 2018.

\begin{tabular}{cllcc}
\hline \multirow{2}{*}{ No. } & \multirow{2}{*}{ Persepsi ibu tentang hypnobirthing } & \multicolumn{2}{c}{ Jumlah } \\
\cline { 3 - 5 } & & f & \% \\
\hline $\mathbf{1}$ & Baik & Kurang & 17 & 56,7 \\
$\mathbf{2}$ & & 13 & 43,3 \\
\hline & Total & $\mathbf{3 0}$ & $\mathbf{1 0 0}$ \\
\hline
\end{tabular}

Berdasarkan tabel 3. dapat di ketahui bahwa terdapat 30 responden 17 responden baik $(56,7 \%)$ dengan persepsi ibu tentang Hypnobirthing kurang $13(43,3 \%)$.
Distribusi frekuensi rasa nyeri pada ibu bersalin normal di Klinik Diana Medan pada Tahun 2018.

Tabel 4. Distribusi frekensi rasa nyeri pada ibu bersalin normal di Klinik Dian Medan tahun 2018 .

\begin{tabular}{|c|c|c|c|}
\hline \multirow[b]{2}{*}{ No } & \multirow[b]{2}{*}{ Pengurangan rasa nyeri } & \multicolumn{2}{|c|}{ Jumlah } \\
\hline & & $\mathbf{f}$ & $\%$ \\
\hline 1 & Nyeri sedang & 18 & 60,0 \\
\hline 2 & Nyeri hebat & 12 & 40,0 \\
\hline & Total & 30 & 100 \\
\hline
\end{tabular}

Berdasarkan tabel 4. dari 30 responden di ketahui bahwa terdapat 18

\section{Analisa Bivariat}

Setelah di ketahui karakteristik masing-masing variabel pada penelitian ini maka analisis di lanjutkan pada tingkat bivariat.Untuk mengetahui hubungan (korelasi ) antara variabel bebas (indenpendent variabel) denagan variabel terikat (dependen variable)

Untuk membuktikan adanya Untuk membuktikan adanya
hubungan yang signifikan antara

Tabel 5. Tabulasi Silang Antara persepsi ibu tentang Hypnoberthing Dengan Pengurangan Rasa Nyeri pada Ibu Bersalin Normal Di klinik Diana Medan pada 2018.

\begin{tabular}{|c|c|c|c|c|c|c|c|c|}
\hline \multirow{3}{*}{ No. } & \multirow{3}{*}{$\begin{array}{l}\text { Persepsi ibu } \\
\text { tentangHypnobirthing }\end{array}$} & \multicolumn{4}{|c|}{ Pengurangan Rasa Nyeri } & \multirow{2}{*}{\multicolumn{2}{|c|}{ Total }} & \multirow{3}{*}{$\begin{array}{c}\text { Sign } \\
p\end{array}$} \\
\hline & & \multicolumn{2}{|c|}{$\begin{array}{l}\text { Nyeri } \\
\text { Sedang }\end{array}$} & \multicolumn{2}{|c|}{$\begin{array}{l}\text { Nyeri } \\
\text { Hebat }\end{array}$} & & & \\
\hline & & f & $\%$ & $\mathbf{f}$ & $\%$ & f & $\%$ & \\
\hline 1 & Baik & 14 & 46,7 & 3 & 10,0 & 17 & 56,7 & \multirow{3}{*}{0,013} \\
\hline 2 & Kurang & 4 & 13,3 & 9 & 30,0 & 13 & 43,3 & \\
\hline & Total & 18 & 60 & 12 & 40 & 30 & 100 & \\
\hline
\end{tabular}

responden nyeri sedang $(60,0 \%)$, nyeri hebat terdapat 12 responden $(40,0 \%)$.

variabel bebas dengan variabel terikat digunakan analisis Chi-square, pada batas kemaknaan perhitungan statistik dengan kepercayaan $95 \%$ dan a=0,013. Apabila hasil perhitungan menunjukkan nilai p-value $<(0,013)$ maka artinya kedua variabel secara statistik mempunyai hubungan yang signifikan 
Berdasarkan Tabel 5. dapat di ketahui bahwa mayoritas ibu yang melakukan persepsi ibu tentang Hypnobirthingyang baikada 17 responden $(56,7 \%)$ dan yang mengalami nyeri sedang sebanyak 18responden $(60,0 \%)$. Dan minoritas ibu yang melakukan persepsi ibu tentang hypnobirthing yang kurang baiksebanyak 13 responden $(43,3 \%)$ dan

\section{PEMBAHASAN}

\section{Hypnobirthing di Klinik Bersalin Diana Medan Tahun 2018 \\ Hypnobirthing berasal dari kata} hypnosis dan birthing. Hypnosis yang berasal dari kata hypnos(bahasa yunani) adalah nama Dewa Tidur. Arti tidur disini adalah pikiran yang tenang. Sedangkan birthing (bahasa inggris) berarti proses persalinan. Persepsi ibu tentang Hypnobirthing dikembangkan oleh Marie F. Mongan, M.Ed sejak tahun 1959 berdasarkan teori Dr.Grantley Dick-read (seorang ahli kebidanan inggris yang hidup di tahun 1890-1959), yang juga dikenal sebagai bapak kelahiran alami. Tahun 2002, Hypnobirthing dikembangkan di indonesia oleh Lanny kuswandy.

\section{Manfaat Hypnobirthing}

Merupakan formula dasar yang alami dari point management, pengobatan ini tidak memiliki potensi efek samping terhadap bayiMampu menghadirkan rasa nyaman, rileks dan aman menjelang kelahiran.Menurunkan stress ketakutan dan kekhawatiran menjelang kelahiran.Membuat anda tetap pada kondisi terjaga dan sadar.Meningkatkan kadar endorphin dalam tubuh untuk mengurangi rasa nyeri pada saat kontraksi.

Endorphin adalah neuropretidine yang dihasilkan tubuh pada saat relaksasi atau tenang.Pada saat stress, endorphin terhalang oleh kortisol.Endorphin dihasilkan di otak dan disusunan saraf tulang belakang. yang mengalami nyeri hebat sebanyak 12 responden $(40,0 \%)$

Berdasarkan hasil uji chi-square di peroleh tingkat kepercayaan $95 \%$ dengan nilai $=0,013$, dapat di ketahui nilai $\mathrm{p}=0,013<0,05$. Maka dapat di simpulkan ada hubungan metode hypnoberthing dengan pengurangan rasa nyeri pada ibu bersalin normal di Klinik Diana Medan.

Pelaksanaan persepsi ibu tentang

Pengurangan rasa nyeri pada ibu bersalin normal di Klinik Bersalin Diana Medan Tahun 2018

Nyeri pada persalinan adalah nyeri kontraksi uterus yang dapat mengakibatkan peningkatan aktiftar sistem syaraf simpatis.Nyeri yang hebat pada persalinan dapat menyebabkan perubahan-perubahan fisiologis tubuh, seperti kenaikan tekanan darah, kenaikan denyut jantung, dan kenaikaan jalan perrnafasan, dan apabila tidak segera di atasi, maka keadaan ini meningkatkanrasa khuatir, tegang takut dan stres.Association for the study of pain mendefenisikan bahwa nyeri merupakan pengalaman emosional dan sensori yang tidak menyenangkan yang muncul dari kerusakan jaringan secara aktual atau potensial atau menunjukan adanya.

\section{Fisiologi nyeri persalinan}

Fisiologi (alur) terjadinya nyeri dalam persalinan, yaitu;

Pada kala I nyeri sifatnya VISERAL, di timbulkan oleh karena kontraksi uterus dan dilatasi serviks yang dipersyarafi oleh serabut aferen simpatis dan ditransmisikan ke medula spinalis pada segmen T10-L1(thorakal 10 Lumbal 1) melalui serabut syaraf delta dan serabut syaraf $\mathrm{C}$ yang berada dari dinding lateral fundus uteri

Pada kala II merupakan nyeri somatik yang di transmisikan melalui virus pudendal yang berasal dari S2-S4.Pada kala II ini intensitas nyerinya terasa lebih nyeri dan terolkalisasi.Secara lebih terperinci, fisiologi nyeri 
persalinan dapat dijelaskan sebagai berikut :

Pada kala I

Nyeri dihasilkan oleh dilatasi serviks dan SBR serta distensi uterus.Intensitas kala I akibat dari kontraksi uterus involunter nyeri di rasakan dari pinggang dan menjalar keperut.Kualitas nyeri bervariasi. Sensi inpuls dari uterus sinapsnya pada thorakal 10,11,12, dan lumbal 1. Mengurangi nyeri pada fase ini dengan memblock daerah diatasnya.Fase dari transisi dari kala I sampai kala IISelama fase transisi ibu biasanya akan merasakan sensi nyeri yang amat sangat. Ekspresi tampak berdaya dan menunjukan kemampuan penurunan mendengar dan konsentrasi.

Pada kala II

Nyeri diakibatkan oleh tekanan kepala janin pada pelvis.Distensi struktur pelvis dan tekanan pada plekus lumbo sakralis. Adabeberapa faktor yang mempengaruhi nyeri;Intensitas dan lamanya kontraksi Rahim.Besarnya janin dan keadaan umumnya pasien Pasien dengan primipara pada usia muda dan usia tua Besarnya janin atau jalan lahir yang sempitKelelahan dan kurang tidur.

Hubungan persepsi ibu tentang Hypnobirthing Dengan Pengurangan Rasa Nyeri Pada Ibu Bersalin Normal di Klinik Bersalin Diana Medan Tahun 2018

Berdasarkan tabel 4.6 tentang metode hypnobirthing dengan pengurangan rasa nyeri pada ibu bersalin normal di klinik Diana Medan tahun 2018 yangmenunjukan ibu yang melakukan hypnobirthing sebanyak 30 responden, ibu bersalin yang melakukan metoden hypnobirthing dengan baik ada 17 responden $(56,7 \%)$, dan yang kurang melakukan hypnobirthing ada 13 responden $(43,3 \%)$.

Berdasarkan hasil uji chi-square di peroleh tingkat kepercayaan $95 \%$ dengan nilai $=0,013$, dapat di ketahui nilai $\mathrm{p}=0,013<0,05$ yang artinya $\mathrm{Ha}$ di terima Ho di tolak membuktikan bahwa ada hubungan persepsi ibu tentang hypnobirthing dengan pengurangan rasa nyeri pada ibu bersalin normal di Klinik Diana Medan.Setelah dilakukan uji stastik dengan menggunakan uji chiSquare pada tingkat kepercayaan 95\% dengan $<\alpha 0,05$ di peroleh nilai $\rho$ value $=0,013$ maka $\rho=(0,13)<\alpha(0,05)$.

Hypnobirthing merupakan salah satu teknik otohipnosis (self hipnosis) yaitu upaya alami menanamkan niat positif/sugesti kejiwa/pikiran bawah sadar dalam menjalani masa kehamilan dan persiapan persalinan. Dengan demikian, setiap ibu hamil dapat menikmati indahnya masa kehamilan dan lancarnya proses persalinan.

Berdasarkan hasil penelitian yang dilakukan oleh Meztika riza helty, SKM dengan judul perbandingan intensitas nyeri pada ibu bersalin primipara dengan multipara kala I fase aktif yang diberikan terapy Hypnobirthing di Klinik bersalin Sumiariani Medan johor Tahun 2016. Mayoritas ibu inpartu primipara berada pada tingkat nyeri sedang sebanyak 10 responden $(83,3 \%)$ sedangkan pada ibu inpartu multipara berada pada tingkat nyeri ringan sebanyak 9 responden $(75,0 \%)$. Bagaimana perbandingan tingkat nyeri pada ibu inpartu primipara dengan multipara kala I fase aktif dengan kala I fase aktif yang diberi perlakuan teknik Hypnobirthing dengan uji $\mathrm{T}$ independen nilai hitung sebesar 5,234 dan nilai $P$ volume 0,000 $(\mathrm{P}>0,05)$. Penilitian ini dapat disimpulkan bahwa ada hubungan antara persepsi ibu tentang Hypnobirthing dengan pengurangan rasa nyeri pada ibu bersalin normal.

Menurut asumsi peneliti yang dilakukan di Klinik Diana medan Tahun 2018, menyatakan bahwa persepsi ibu tentang hypnobirthing dapat mengurangi rasa nyeri pada ibu bersalin normal, danHypnobirthing merupakan salah satu teknik otohipnosis (self hipnosis) yaitu upaya alami menanamkan niat positif/sugesti 
kejiwa/pikiran bawah sadar dalam menjalani masa kehamilan dan persiapan persalinan. Dengan demikian, setiap ibu hamil dapat menikmati indahnya masa kehamilan dan lancarnya proses persalinan.Nyeri pada persalinan merupakan nyeri kontraksi uterus yang dapat mengakibatkan peningkatan aktiftas sistem syaraf simpatis. Nyeri yang hebat pada persalinan dapat menyebabkan perubahan-perubahan fisiologis tubuh, seperti kenaikan tekanan darah, kenaikan denyut jantung, dan kenaikaan jalan perrnafasan, dan apabila tidak segera di atasi, maka

\section{KESIMPULAN DAN SARAN Kesimpulan}

Berdasarkan hasil responden dan data yang di peroleh dari data primer oleh peneliti di Klinik Diana Medan Tahun 2018 dari 30 responden berdasarkan hubungan persepsi ibu tentang hypnobirthing dengan pengurangan rasa nyeri pada ibu bersalin normal di Klinik Diana Medan yang kurang melakukan hypnobirthing ada $11(36,7 \%)$

Distribusi frekuensi Ibu bersalin dengan melaksanakan persepsi ibutentang Hypnobirthing, mayoritas ibu yang melakukanpersepsi ibu tentang hypnobirthing dengan baik di antaranya 17 responden $(56,7 \%)$ dan yang kurang melakukan persepsi ibu tentang hypnobirthing sebanyak 13 responden $(43,3 \%)$, dan yang mengalami nyeri sedang sebanyak 18 responden $(60,0 \%)$, dan yang mengalami nyeri hebat sebanyak 12 responden $(40,0 \%)$.

Dari hasil uji person chi square di ketahui nilai $\mathrm{p}=0,040<0,05$. Pada penelitian ini membuktikan bahwa ada hubungan antara pesrsepsi ibu tentang Hypnobirthing dengan pengurangan rasa nyeri pada Ibu bersalin normal.

\section{Saran}

\section{Bagi Responden}

Agar lebih banyak bertanya kepada Bidan atau mencari informasi lewat media tentang persrsepsi-persepsi keadaan ini meningkatkanrasa khuatir, tegang takut dan sitres.dari hasil penelitian yang dilakukan di Klinik Diana Medan Tahun 2018, dalam penelitian ini bahwa ada hubungan metode hypnobirthing dengan pengurangan rasa nyeri pada ibu bersalin normal.. Dalam hal ini diharapkan ibu-ibu yang menjalani proses persalinan agar melakukan metode hypnobirthing setiap bersalin dengan tujuan untuk mengurangi rasa nyeri cemas ketika menjalani proses persalinan.

Tahun 2018 periode juni- Januari Tahun 2018 s/d 2019 kesimpulan yang di ambil adalah :

Distribusi frekuensi pengurangan rasa nyeri pada ibu bersalin diketahui bahwa dari 30 responden, mayoritas ibu bersalin yang melakukan metode hypnobirthing dengan baik ada $19(63,3 \%)$ dan minoritas ibu bersalin

yang dapat digunakan dalam persalinan untuk mengurangi rasa sakit saat menggunakan persepsi ibu tentang Hypnobirthing

\section{Bagi Tempat Penelitian}

Untuk dapat di promosikan persalinan dengan persepsi ibu tentang Hypnoberthing dan senantiasa turut serta dalam memberikan informasi kepada ibu-ibu tentang persiapan selama kehamilan dan persalinan dengan menggunakan persepsi ibu tentang hypnoberthing, keuntungan dan manfaat yang didapat ibu dengan melakukan persepsi ibu tentang hypnoberthing danDisarankan kepada bidan untuk dapat membantu ibu-ibu bersalin dalam penyampaian pentingnya penggunaan persepsi ibu tentang Hypnoberthing dalam kehamilan dan persalinan

\section{Bagi Institusi Pendidikan}

Diharapkan kepada institusi pendidikan agar membantu mahasiswa dalam mengembangkan penelitian dan dapat digunakan sebagai data dasar selanjutnya sehingga dapat menjadi 
bahwa kajian dalam kegiatan proses pembelajaran sehingga mahasiswa mempunyai bekal atau pun memiliki pengetahuan tentang metode hypnobirthing.

\section{Bagi Peneliti}

Disarankan bagi peneliti agar melakukan uji validitas reabilitas untuk kesempurnaan hasil penelitian. Penelitian yang dilakukan ini dapat di kembangkan lagi di gunakan lagi

\section{KEPUSTAKAAN}

1. Meztika $\mathrm{R}$ helty. perbandingan intensitas nyeri pada ibu bersalin primipara dengan multipara kala I fase aktif yang diberikan terapy hypnobirthing di Klinik bersalin sumiariani Medan Johor. 2016;

2. malini Y. Hubungan pengetahuan ibu bersalin dengan metode hypnobirthing. 2014;

3. Istikhomah $\mathrm{H}$, Mumpuni Dap. Kesiapan Psikologis Ibu Hamil Trimester Iii Dalam Persiapan Persalinan Pasca Relaksasi Hypnobirthing. J Kebidanan Dan Kesehat Tradis. 2016;1(1).

4. Octavani D. prosedur pencegahan infeksi oleh Bidan Praktik Mandiri di wilayah kerja Puskesmas Kabanjahe. Repos Usu [Internet]. 2014; Available from: repository.usu.ac.id/bitstream/12345 6789/54481/5/Chapter I.pdf

5. Sondakh JJS. Asuhan kebidanan persalinan dan bayi baru lahir. Jakarta: Erlangga. 2013;

6. Sari EP, Rimandini KD. Asuhan Kebidanan Persalinan (Intranatal Care). Jakarta Timur: CV. Trans Info Media; 2014.

7. Johariah WE. Buku Ajar Asuhan Kebidanan Persalinan dan Bayi Baru Lahir. Jakarta: TIM; 2012.

8. Walyani ES, Purwoastuti E. Asuhan Kebidanan Persalinan dan bayi baru lahir. Yogyakarta: Pustaka Baru Press; 2015.

9. Kuswanti I, Melina F. Askeb II Persalinan. Yogyakarta: Pustaka Belajar. 2014;

10. Astuti I, Noviyanti N. Pengaruh sebagai referensi atau bahan perbandingan penelitian-penelitian.

\section{Bagi Penelitian Selanjutnya}

Bagi penelitian selanjutnya di sarankan untu meneliti faktor-faktor lain yang belum diteliti dalam penelitian ini dengan sampel yang lebih besar dari ruang lingkup yang lebih luas sehingga dapat meningkatkan ketelitian dalam penelitian.

Hypnobirthing Terhadap Tingkat Nyeri Dan Kemajuan Persalinan Pada Ibu Bersalin Di Bpm Kota Cimahi. Southeast Asian J Midwifery. 2015;1(1):43-7.

11. Judha M, Sudarti FA. Teori pengukuran nyeri dan nyeri persalinan. Jogjakarta, Muha Med. 2012;

12. Maryunani A. Nyeri dalam persalinan "teknik dan cara penanganannya." Jakarta Trans Info Media. 2010;

13. Ilmiah WS. Buku Ajar Asuhan Persalinan Normal. Yogyakarta: Nuha Medika; 2015.

14. Kuswandi L. Keajaiban HypnoBirthing. yogyakarta: Pinang merah; 2013.

15. DM D. Melahirkan dengan menyenangkan. yogyakarta: Pinang merah; 2011.

16. Chandyy MD. Petunjuk-petunjuk mudah melahirkan tanpa rasa sakit. Buku Biru; 2011.

17. Nurasiah A, Rukmawati A, Badriah DL. Asuhan persalinan normal bagi bidan. Bandung PT Refika Aditama. 2012;

18. N syakhri.hubungan pengetahuan ibu bersalin tentang hypnobirthing dan manfaat hypnobirthing. Inst Kesehat Helv. 2015;

19. Muhammad I. panduan-panduan karya tulis ilmiah bidang kesehatan menggunakan metode ilmiah. Bandung: Cipta Pustaka Media Perintis; 2015. 